\title{
SHORT AND LONG TERM CHANGES IN TYROSINE HYDROXYLASE ACTIVITY IN RAT BRAIN AFTER SUBTOTAL DESTRUCTION OF CENTRAL NORADRENERGIC NEURONS ${ }^{1}$
}

\author{
ANN LINN ACHESON AND MICHAEL J. ZIGMOND
}

Department of Biological Sciences, University of Pittsburgh, Pittsburgh, Pennsylvania 15260

\begin{abstract}
The administration of 6-hydroxydopamine into the cerebroventricles of the rat produced a rapid and permanent decrease of norepinephrine in hippocampus due to an apparent degeneration of central catecholaminergic nerve terminals. The decrease in norepinephrine levels was accompanied by a decrease in the activity of the rate-limiting biosynthetic enzyme, tyrosine hydroxylase. However, the decrease in enzyme activity was less pronounced than the decrease in norepinephrine levels, resulting in an increase in the ratio of tyrosine hydroxylase activity to norepinephrine content. This relative increase in enzyme activity was shown to result from two processes. Within $36 \mathrm{hr}$ after the lesion, the apparent $V_{\max }$ had decreased in parallel to the norepinephrine loss. However, there was an apparent activation of the remaining enzyme molecules. This activation was only detectable in the presence of subsaturating cofactor concentrations and at a $\mathrm{pH}$ above the $\mathrm{pH}$ optimum. The activation resembled that produced in control samples by in vitro adenosine $3^{\prime}: 5^{\prime}$-monophosphatedependent protein-phosphorylating conditions, and incubation under these conditions had no further effect on enzyme activity. The activation was followed by a gradual increase in the apparent $V_{\max }$ of tyrosine hydroxylase toward control values. This increase was preceded by a 2 -fold rise in the amount of enzyme present in the region of the locus coeruleus, an area rich in noradrenergic cell bodies. The time course of the increased $V_{\max }$ in terminal fields appeared to be related to their proximity to the locus coeruleus, since it was more rapid for cerebellum (peak activity, 7 days) than for hippocampus (21 days) and probably represented a 3- to 4-fold increase in the amount of tyrosine hydroxylase per residual terminal. The increase in the $V_{\max }$ was accompanied by a return to a basal activation state of the enzyme molecules and a restoration of the ability of in vitro proteinphosphorylating conditions to increase enzyme activity. These short and long term alterations in tyrosine hydroxylase activity after 6-hydroxydopamine treatment may represent adaptive responses to the lesion.
\end{abstract}

Pharmacological treatments which reduce the activation of catecholamine receptors often are followed by an increase in the activity of the rate-limiting enzyme, tyrosine hydroxylase (TH). In short term experiments (minutes), changes in TH activity appear to be due to an increase in the affinity of existing molecules for pterin cofactor (Zivkovic et al., 1974; Lovenberg and Bruckwick,

\footnotetext{
' Support for this research was provided by United States Public Health Service Grant MH-20620. M. J. Z. is a Research Career Scientist Awardee (MH-00058). Dr. Edward M. Stricker participated in discussions which led to many of the ideas presented in this paper. Helpful comments were provided by Dr. Linda Toth Kennedy. Dr. Tong H. Joh provided the tyrosine hydroxylase antibody and assisted in the design of the immunoinhibition protocol. We thank Mr. Michael Westfall for preparation of the figures, and Ms. Karol Tinsley for assisting in the preparation of the manuscript. Preliminary reports of some of these results were presented at the Ninth and Tenth Annual Meetings of the Society for Neuroscience, 1979 and 1980.
}

1975). In longer term studies (days), an increase in the amount of TH protein is seen (Mueller et al., 1969; Reis et al., 1975). These two types of alterations in TH activity may be part of the homeostatic capacity of catecholaminergic neurons, permitting an increase in transmitter synthesis and release under conditions of decreased receptor activity.

Subtotal destruction of catecholaminergic terminals often produces relatively few gross physiological or behavioral impairments, and even when severe disruptions occur, they are frequently temporary (Laverty and Taylor, 1970; Uretsky and Iversen, 1970; Ungerstedt, 1971a; Gauthier et al., 1972; Zigmond and Stricker, 1972). The effects of pharmacological antagonists on $\mathrm{TH}$ activity suggested to us that the lack of major functional deficits following such lesions might be due in part to similar changes in $\mathrm{TH}$ activity within residual catecholaminergic nerve terminals brought about by a lesion-induced de- 
crease in receptor activation. Such changes might result in an adaptive increase in the capacity of residual terminals to synthesize and release transmitter (Zigmond and Stricker, 1974; Stricker and Zigmond, 1976). In an effort to examine this hypothesis, we destroyed norepinephrine (NE)-containing nerve terminals in rat brain using the neurotoxin, 6-hydroxydopamine (6HDA). We then examined TH activity in brain areas rich in noradrenergic cell bodies (locus coeruleus) or their terminals (hippocampus and cerebellum). Our observations support the concept of adaptive changes in $\mathrm{TH}$ underlying recovery from subtotal destruction of catecholaminergic systems.

\section{Materials and Methods}

Materials. Except where indicated below or in the references provided, all reagents were purchased from Fisher Scientific Co., Pittsburgh, PA, and were of the highest obtainable purity.

Animals. Male Sprague-Dawley rats (Zivic Miller Laboratories, Allison Park, PA), weighing 150 to $250 \mathrm{gm}$, were allowed free access to Purina Rodent Laboratory Chow (Ralston Purina, St. Louis, MO) and tap water and were housed separately in hanging wire cages illuminated by fluorescent lights from 7 AM to 7 PM. Animals were allowed to adapt to their home cages for at least 3 days prior to lesioning. Animals were anesthetized with ether and then received 6-hydroxydopamine hydrobromide (Sigma, St. Louis, MO) or vehicle $(20 \mu \mathrm{l}$ of a $0.9 \% \mathrm{NaCl}$ solution containing $0.1 \%$ ascorbic acid) into the cerebrospinal fluid by way of the lateral ventricle. Unless otherwise stated, lesioned animals received $250 \mu \mathrm{g}$ of $6 \mathrm{HDA}$ (doses indicated are of the free base). In one experiment, animals were pretreated with desmethylimipramine $(25$ $\mathrm{mg} / \mathrm{kg}$, i.p., Merrell-National Laboratories, Cincinnati, $\mathrm{OH}) 30 \mathrm{~min}$ prior to anesthetization. Animals were killed by decapitation $36 \mathrm{hr}$ to 21 days after $6 \mathrm{HDA}$ treatment and their brains were removed rapidly and placed on ice. An area containing locus coeruleus (average weight, 2 mg; R. E. Zigmond et al., 1974), the hippocampus (average weight, $120 \mathrm{mg}$ ), and the cerebellum (average weight, $155 \mathrm{mg}$ ) were removed bilaterally. Tissues were frozen immediately on dry ice and stored at $-70^{\circ} \mathrm{C}$ for up to several weeks prior to assay.

Determination of TH activity. The soluble TH activity of crude homogenates was measured as previously described (Kapatos and Zigmond, 1979; Acheson et al., 1981). Tissues were homogenized in $50 \mathrm{~mm}$ Tris- $\mathrm{HCl}$ buffer, $\mathrm{pH} 6.0$, and centrifuged at $40,000 \times g$ for $30 \mathrm{~min}$. Aliquots of the supernatant were incubated in the presence of $\mathrm{L}-\left[1-{ }^{14} \mathrm{C}\right]$ tyrosine $(54 \mathrm{mCi} / \mathrm{mmol}$, New England Nuclear, Boston, MA) and 6-methyl-5,6,7,8-tetrahydropterin-HCl $\left(6 \mathrm{MPH}_{4}\right.$, Calbiochem-Behring Corp., La Jolla, CA). The concentration of tyrosine $(75 \mu \mathrm{M})$ was subsaturating, since higher concentrations resulted in inhibition of TH activity in our assay system (Kapatos and Zigmond, 1979). The reaction was carried out in the presence of air $\left(21 \% \mathrm{O}_{2}\right)$; thus, the concentration of $\mathrm{O}_{2}$ was subsaturating also.

In several experiments, the apparent Michaelis constant, $K_{m}$, for $6 \mathrm{MPH}_{4}$ and $V_{\max }$ were determined. In these studies, the concentrations of $\mathrm{O}_{2}$ and tyrosine were held constant and the concentration of $6 \mathrm{MPH}_{4}$ was varied between 0.2 and $4.0 \mathrm{mM} . K_{m}$ and $V_{\max }$ values were determined by the method of Wilkinson (1961) using a Texas Instruments TI59 programmable calculator (Barnes and Waring, 1980). This method is based on statistical weighting of the data followed by a transformation to the reciprocal values $1 / v$ and $1 / s$ and linear regression analysis. The weighting factor used is the velocity to the fourth power $\left(v^{4}\right)$. The standard error of the apparent $K_{m}$ and $V_{\max }$ values also were determined from this analysis. Since neither tyrosine nor $\mathrm{O}_{2}$ were saturating, true maximal velocities and $K_{m}$ values were not determined in this study.

A Tris/acetate buffer was used, the $\mathrm{pH}$ of which was either optimal for the preparation (hippocampus, $\mathrm{pH}$ 6.2; cerebellum, 6.1; locus coeruleus, pH 5.9 to 6.3 ; Fig. 1) or was above this $\mathrm{pH}$ optimum. Tris/acetate was used despite the fact that it does not have $\mathrm{pK}_{a}$ values within this range, because it results in higher $\mathrm{TH}$ activity than buffers which have the correct $\mathrm{pK}_{a}$ values (Acheson et al., 1981), presumably because Tris serves to inhibit the conversion of $6 \mathrm{MPH}_{4}$ to a form which is not reducible by dihydropteridine reductase (Nielsen et al., 1962). The pH of the reaction mixture was not significantly different from that of the Tris/acetate buffer.

The $\mathrm{L}-\left[1{ }^{-14} \mathrm{C}\right]$ dihydroxyphenylalanine (DOPA) formed during the initial reaction was decarboxylated subsequently by addition of an excess of aromatic L-aminoacid decarboxylase and a Tris/acetate buffer, $\mathrm{pH} 7.2$ to 7.5 , selected to bring the final $\mathrm{pH}$ of the reaction mixture to 6.8. Finally, ${ }^{14} \mathrm{CO}_{2}$ was trapped and quantified using liquid scintillation spectrometry. The specificity of the assay for tyrosine hydroxylation and its linearity with

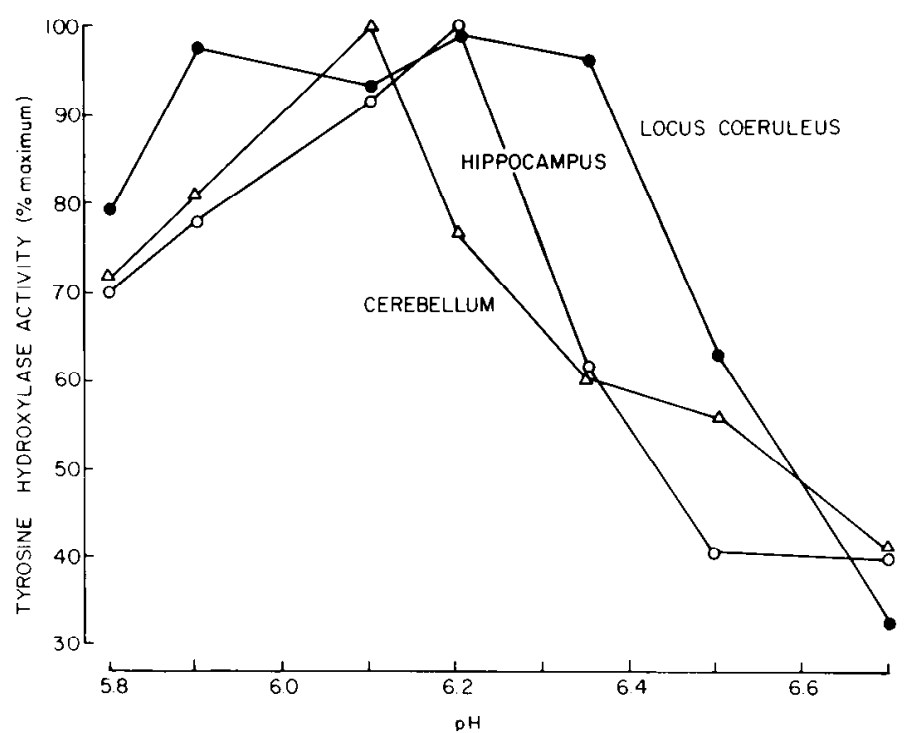

Figure 1. pH optimum of soluble TH activity from hippocampus, cerebellum, and locus coeruleus. Enzyme activity was measured in Tris/acetate buffer with 0.7 to $1.5 \mathrm{mM}_{6 \mathrm{MPH}}$ and $75 \mu \mathrm{M} \mathrm{L}-\left[1-{ }^{\mathrm{I}} \mathrm{C}\right]$ tyrosine as a function of assay $\mathrm{pH}$. Enzyme activity was expressed as a percentage of maximal activity for hippocampus $(O)$, cerebellum $(\triangle)$, and locus coeruleus $(O)$, respectively. The $40,000 \times g$ supernatant from a homogenate served as the source of soluble TH. Each point represents the mean of five animals. 
time and amount of protein were determined within the ranges used (Acheson et al., 1980, 1981). The sensitivity of the assay was such that all values were at least twice the value of blank controls.

Adenosine $3^{\prime}: 5^{\prime}$-monophosphate (cAMP)-dependent protein-phosphorylating conditions. Samples were preincubated for $10 \mathrm{~min}$ at $30^{\circ} \mathrm{C}$ in the presence of $1 \mu \mathrm{g} /$ $\mu \mathrm{l}$ of cAMP-dependent protein kinase (partially purified from bovine heart; Miyamoto et al., 1969), $0.5 \mathrm{~mm}$ adenosine 5 -triphosphate (ATP), $0.2 \mathrm{~mm}$ cAMP, $1.0 \mathrm{~mm}$ $\mathrm{MgCl}_{2}$, and $2.0 \mathrm{~mm}$ theophylline (Sigma) in $75 \mathrm{~mm}$ Tris/ acetate, $\mathrm{pH}$ 6.0. Control samples were preincubated with $75 \mathrm{~mm}$ Tris/acetate buffer, $\mathrm{pH} 6.0$, containing $1 \mu \mathrm{g} / \mu \mathrm{l}$ of bovine serum albumin (BSA, Fraction V, Sigma). The preincubation was terminated by placing the sample on ice. $\mathrm{TH}$ activity in the samples was assayed then in the presence of $2 \mathrm{~mm}$ disodium ethylenediaminetetra-acetic acid (EDTA; Fisher Scientific Co.) to inhibit further phosphorylation.

Determination of amount of TH protein. Animals were treated with $6 \mathrm{HDA}$ or vehicle and killed 5 to 21 days later. The area containing locus coeruleus was removed, and two locus coeruleus pairs were pooled and homogenized in $450 \mu \mathrm{l}$ of $50 \mathrm{~mm}$ Tris-HCl buffer, $\mathrm{pH}$ 6.0, containing $0.1 \%$ bovine serum albumin. Homogenates were centrifuged at $40,000 \times g$ for $30 \mathrm{~min}$, and the supernatant served as the source of TH. Antibodies specific to TH were a gift from Dr. T. H. Joh and were raised in rabbits from enzyme purified from rat adrenal glands by the method of Joh et al. (1973). The IgG fraction was precipitated from the serum at $50 \%$ saturation with ammonium sulfate and resuspended in $0.9 \% \mathrm{NaCl}$. A $10-\mu \mathrm{l}$ aliquot of $0.9 \% \mathrm{NaCl}$ containing various amounts of antibody was added to a $20-\mu l$ aliquot of tissue supernatant. Samples then were incubated at room temperature for $1 \mathrm{hr}$ with occasional shaking and centrifuged at $10,000 \times g$ for 10 min. A $10-\mu$ l aliquot of the resulting supernatant was assayed for TH activity as described above. 'The amount of antibody required to inhibit TH activity completely (the equivalence point) was estimated by graphical analysis.

Catecholamine assay. NE and dopamine (DA) levels were measured as previously described (Saller and Zigmond, 1978). Endogenous catecholamines were methylated by catechol- $O$-methyltransferase, using radiolabeled $S$-adenosyl-L-[methyl $\left.{ }^{3} \mathrm{H}\right]$ methionine $(80 \mathrm{Ci} / \mathrm{mmol}$, New England Nuclear) as a methyl donor. The methylated compounds then were separated using silica gel thin layer chromatography and eluted with borate buffer, $\mathrm{pH} 10.0$. The compounds were separated further by solvent extraction and quantified using liquid scintillation spectrometry. Final values were determined using internal standards carried through the entire assay. The assay was determined to be linear with the concentration of catecholamine within the ranges used. The average sensitivity of the assay was $10 \mathrm{pg}$ for DA and $20 \mathrm{pg}$ for NE. All values were at least three times blank for DA and twice blank for NE.

Determination of sample protein content. Soluble protein content in each of the brain regions was determined using the Bio-Rad Protein Assay Kit (Bio-Rad Laboratories, Richmond, CA) with BSA as the standard. This assay is based on the binding of Coomassie brilliant blue G-250 dye to protein, followed by spectrophotometric quantification.

\section{Results}

NE content in hippocampus and locus coeruleus after $6 H D A$. Rats were lesioned with $250 \mu \mathrm{g}$ of $6 \mathrm{HDA}$ administered intraventricularly. Thirty-six hours or 21 days later, the animals were killed and the hippocampus, cerebellum, and locus coeruleus region were removed for analysis of NE content. $6 \mathrm{HDA}$ treatment resulted in an immediate and apparently permanent decrease in the $\mathrm{NE}$ content of noradrenergic terminal fields (hippocampus and cerebellum) to approximately $20 \%$ of control values (Table I). However, this depletion was not accompanied by any change in the NE content of the locus coeruleus region (Table I). Using a synaptosome-rich $P_{2}$ fraction prepared from hippocampus, we also have measured high affinity NE uptake, a specific characteristic of noradrenergic terminals, and found an equivalent decrease in the initial transport velocity (Acheson et al., 1980). Collectively these observations suggest that $6 \mathrm{HDA}$ caused a degeneration of noradrenergic nerve terminals without significant loss of cell bodies and are consistent with previous reports (Jonsson, 1980).

TH activity $36 \mathrm{hr}$ after $6 H D \mathrm{~A}$ treatment. Rats given $250 \mu \mathrm{g}$ of $6 \mathrm{HDA}$ were killed $36 \mathrm{hr}$ later and hippocampal TH activity was measured. When enzyme activity was measured at the $\mathrm{pH}$ optimum (pH 6.2) and in the presence of a saturating concentration of cofactor $(3.0 \mathrm{~mm})$, activity was reduced to $23 \%$ of control, an amount comparable to the loss of NE. In contrast, when TH activity was assayed at a suboptimal $\mathrm{pH}(\mathrm{pH}$ 6.6) and in the presence of a subsaturating concentration of cofactor (1.5 mM), TH activity was reduced to only $86 \%$ of control (Table II).

Short term activation of $\mathrm{TH}$ is usually characterized by an increase in the affinity of the enzyme for its pterin cofactor and in its $\mathrm{pH}$ optimum (Zivkovic et al., 1974;

TABLE I

Norepinephrine content of terminal and cell body regions $36 \mathrm{hr}$ or 21 days after $6 H D A$ lesions ${ }^{a}$

\begin{tabular}{|c|c|c|c|}
\hline & \multicolumn{3}{|c|}{ NE Content } \\
\hline & \multirow{2}{*}{ Control } & \multicolumn{2}{|c|}{ 6HDA } \\
\hline & & $36 \mathrm{Hr}$ & 21 Days \\
\hline & & $\mu g / g m$ & \\
\hline Hippocampus & $0.54 \pm 0.04$ & $\begin{array}{c}0.14 \pm 0.01^{b} \\
(26.2 \%)\end{array}$ & $\begin{array}{c}0.13 \pm 0.01^{b} \\
(24.7 \%)\end{array}$ \\
\hline Cerebellum & $0.25 \pm 0.05$ & $\begin{array}{c}0.07 \pm 0.01^{b} \\
(23.0 \%)\end{array}$ & $\begin{array}{c}0.06 \pm 0.02^{b} \\
(24.0 \%)\end{array}$ \\
\hline Locus coeruleus ${ }^{\prime}$ & $46.5 \pm 3.7$ & $45.7 \pm 3.1$ & $47.4 \pm 4.0$ \\
\hline
\end{tabular}

${ }^{a}$ Animals received an intraventricular injection of $6 \mathrm{HDA}(250 \mu \mathrm{g})$ or saline vehicle and were killed $36 \mathrm{hr}$ or 21 days later. Control values for animals killed $36 \mathrm{hr}$ or 21 days after $6 \mathrm{HDA}$ administration were not significantly different and were pooled. Values represent the mean \pm SEM for eight animals (controls) or for four animals (6HDA-treated). Data are expressed as micrograms per gm, wet weight (NE) or percentage of control (values in parentheses).

${ }^{b}$ Significantly different from control $(p<0.001)$.

${ }^{c} \mathrm{NE}$ values for locus coeruleus are expressed as micrograms per pair. 
'I'ABLE II

Norepinephrine content and tyrosine hydroxylase activity in hippocampus $36 \mathrm{hr}$ after $6 H \mathrm{HA}$ lesions ${ }^{n}$

\begin{tabular}{|c|c|c|c|}
\hline & \multirow[b]{2}{*}{ NE Cuntent } & \multicolumn{2}{|c|}{ Tyrosine Hydroxylase Activity ${ }^{h}$} \\
\hline & & $\begin{array}{c}\mathrm{pH} 6.2 \\
3{\mathrm{mM} 6 \mathrm{MPH}_{4}}^{2}\end{array}$ & $\begin{array}{l}\mathrm{pH} 6.6 \\
1.5 \mathrm{mM} \\
6 \mathrm{MPH}_{4}\end{array}$ \\
\hline & $\mu g / g m$ & \multicolumn{2}{|c|}{$\mathrm{pmol} / \mathrm{mg}$ protein $/ \mathrm{min}$} \\
\hline Control & $0.57 \pm 0.07$ & $12.31 \pm 0.92$ & $3.30 \pm 0.20$ \\
\hline $6 \mathrm{HDA}$ & $\begin{array}{c}0.12 \pm 0.03^{r} \\
(22.6 \%)\end{array}$ & $\begin{array}{c}2.87 \pm 0.33^{c} \\
(23.3 \%)\end{array}$ & $\begin{array}{c}2.83 \pm 0.45 \\
(85.8 \%)\end{array}$ \\
\hline
\end{tabular}

${ }^{a}$ Animals received an intraventricular injection of $6 \mathrm{HDA}(250 \mu \mathrm{g})$ or saline vehicle and were sacrificed $36 \mathrm{hr}$ later. Values represent the mean \pm SEM for four animals. Values are expressed as micrograms per $\mathrm{gm}$, wet weight $(\mathrm{NE})$, picomoles of ${ }^{14} \mathrm{CO}_{2}$ per $\mathrm{mg}$ of protein per min $(\mathrm{TH})$, or percentage of control (values in parentheses).

${ }^{b} \mathrm{TH}$ activity was measured under both optimal $(\mathrm{pH} 6.2,3.0 \mathrm{~mm}$ $6 \mathrm{MPH}_{4}$ ) and suboptimal conditions ( $\left.\mathrm{pH} 6.6,1.5 \mathrm{mM}_{6} \mathrm{MPH}_{4}\right)$.

${ }^{c}$ Significantly different from control $(p<0.001)$.

Lovenberg and Bruckwick, 1975; Goldstein et al., 1976; Murrin et al., 1976; Hegstrand et al., 1979; Simon and Roth, 1979). Thus, the relative increase in TH activity (TH activity/NE content) which we observed in the presence of a subsaturating concentration of cofactor and at a suboptimal $\mathrm{pH}$ suggested such an activation. In order to examine this hypothesis, we first assayed TH activity at several $\mathrm{pH}$ values in the presence of a constant, subsaturating concentration of cofactor. We found that, in contrast to the marked $\mathrm{pH}$ optimum observed at pH 6.2 for TH activity in control hippocampus, no such optimum existed within the range of values examined for enzyme prepared from animals that had been lesioned 36 hr previously (Fig. 2). As a result of this change in the shape of the $\mathrm{pH}$ curve, $\mathrm{TH}$ activity from lesioned tissue rose from $24 \%$ of control at $\mathrm{pH} 6.2$ to $76 \%$ of control at pH 6.6.

In addition, we assayed $\mathrm{TH}$ activity in the presence of several cofactor concentrations at a constant, suboptimal $\mathrm{pH}$. We observed that, at a high concentration of cofactor, TH activity was only $47 \%$ of control. However, enzyme activity expressed as a percentage of control increased steadily as cofactor concentration was reduced (Fig. 3). When the data were subjected to a kinetic analysis, we observed that enzyme prepared from $6 \mathrm{HDA}$ treated animals showed an $80 \%$ decline in the apparent $V_{\max }$ but a marked increase in the affinity of the enzyme for cofactor (Fig. 3).

Time course of changes in hippocampal TH activity. We have reported previously that, following $6 \mathrm{HDA}$, there was an elevation in hippocampal $\mathrm{TH}$ activity measured under optimal assay conditions which could be detected at 12 and 21 days but was absent at earlier times postlesion (Acheson et al., 1980). We interpreted this as a gradual increase in the apparent $V_{\max }$ of $\mathrm{TH}$ in residual terminals. The data presented above suggested that, in addition to such long term changes in hippocampal $\mathrm{TH}$ activity, there was a short term activation of the enzyme. Thus, we next sought to determine the relationship between the activation observed $36 \mathrm{hr}$ after the lesion and the increase in maximal TH activity observed at later times.

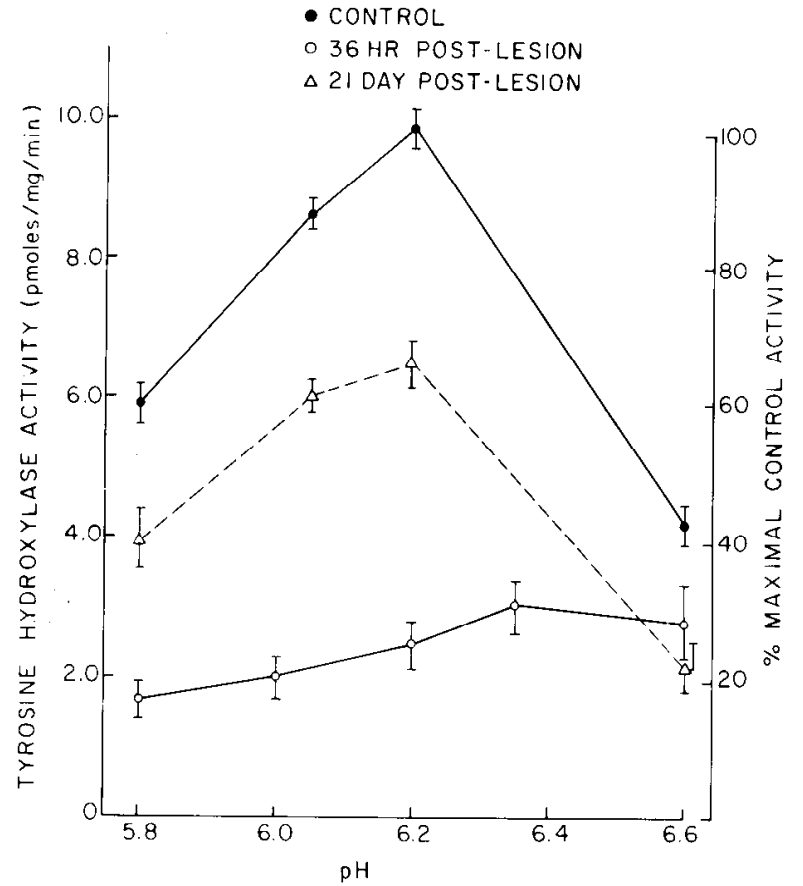

Figure 2. The response of hippocampal TH activity to varying assay $\mathrm{pH}$ as a function of time after 6HDA administration. TH aclivily was measured in the presence of $0.7 \mathrm{mM}^{2} \mathrm{MPH}_{4}$ as a function of assay $\mathrm{pH}$. Data were expressed in terms of both picomoles per $\mathrm{mg}$ of protein per min and percentage of maximal TH activity. The responsiveness of control hippocampal TH activity to varying $\mathrm{pH}(\bigcirc)$ was compared to that of $\mathrm{TH}$ from animals lesioned $36 \mathrm{hr}(O)$ or 21 days $(\triangle)$ previously. Each point represents the mean $( \pm \mathrm{SEM})$ of four animals.

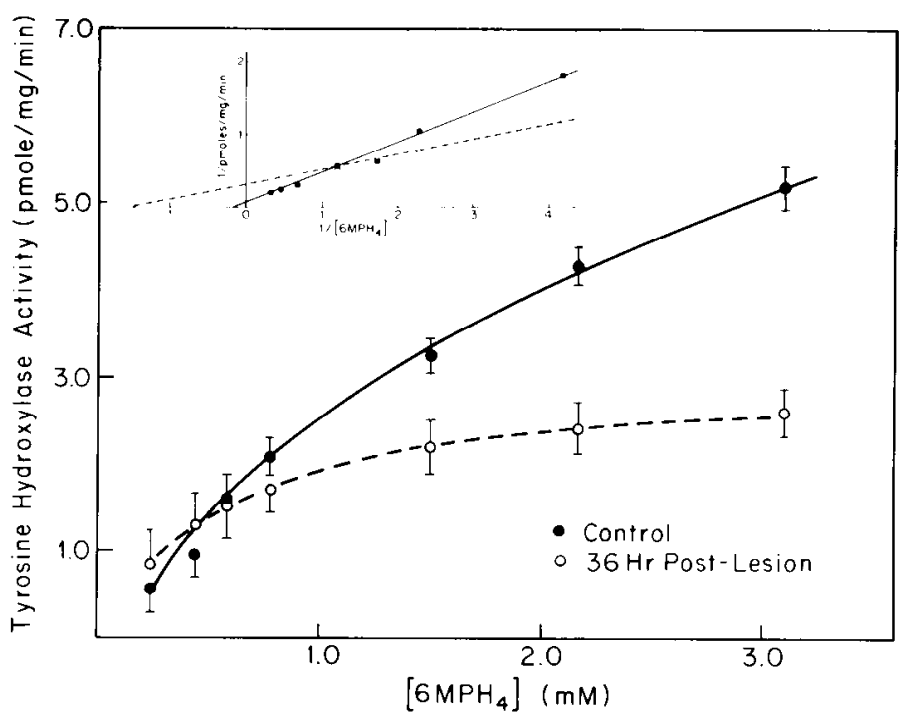

Figure 3. Hippocampal $6 \mathrm{MPH}_{4}$ kinetics $36 \mathrm{hr}$ post-6HDA. $\mathrm{TH}$ activity was measured in the presence of varying concentrations of cofactor in Tris/acetate buffer, $\mathrm{pH} 6.5$, in control hippocampus (O) and in tissue from animals lesioned $36 \mathrm{hr}$ previously $(O)$. The inset shows a Lineweaver-Burk plot of the data. These data represent a typical experiment with each point being the mean of triplicates. Pooled data from five separate experiments yielded the following values: Control: $K_{m}=3.43$ $\pm 0.18 \mathrm{mM}, V_{\max }=9.23 \pm 0.36 \mathrm{pmol} / \mathrm{mg} / \mathrm{min}$; lesioned: $K_{m}=$ $0.72 \pm 0.15 \mathrm{mM}(21 \%$ of control $), V_{\max }=1.83 \pm 0.12 \mathrm{pmol} / \mathrm{mg} /$ $\min (20 \%$ of control). 
$\mathrm{TH}$ activity was assayed at several times post-lesion in the presence of a subsaturating concentration of cofactor. Enzyme activity measured at the $\mathrm{pH}$ optimum, a condition which is relatively insensitive to activation (as shown in Fig. 2), was compared with activity measured at a higher $\mathrm{pH}$ value, where the effects of activation are most pronounced. Consistent with our previous observation, 36-hr post-lesion hippocampal TH activity measured at pH 6.2 was decreased by an amount comparable to the loss of NE content, while activity at $\mathrm{pH} 6.6$ was decreased to a much smaller extent. However, while activity assayed at $\mathrm{pH} 6.6$ remained relatively stable, enzyme activity as assayed at the $\mathrm{pH}$ optimum gradually increased so that by day 21 , it had risen nearly 3 -fold (Fig. 4).

These findings are consistent with our previous evidence for a gradual increase in the activity of the enzyme. Moreover, since the relationship between $\mathrm{TH}$ activity and assay $\mathrm{pH}$ had returned to control by 21 days post6HDA (Fig. 2), it appeared that one mechanism for increased TH activity was gradually replaced by another. These hypotheses were supported by kinetic analysis of TH activity, which indicated a time-dependent increase in the apparent $V_{\max }$ of hippocampal $\mathrm{TH}$ following the lesion, which was accompanied by restoration of the $K_{m}$ for cofactor to control values by 21 days post-6HDA (Table III).

Effect of $6 H D A$ on $T H$ activity in the absence of $N E$ depletion. In addition to destroying $\mathrm{NE}$-containing terminals, 6HDA damages dopaminergic terminals and may produce some less specific damage as well (Hedreen, 1975; Jonsson, 1980). In an effort to determine whether the effects observed here resulted from the loss of NE terminals, animals were pretreated with desmethylimipramine $(25 \mathrm{mg} / \mathrm{kg}$, i.p.) $30 \mathrm{~min}$ prior to the administra-

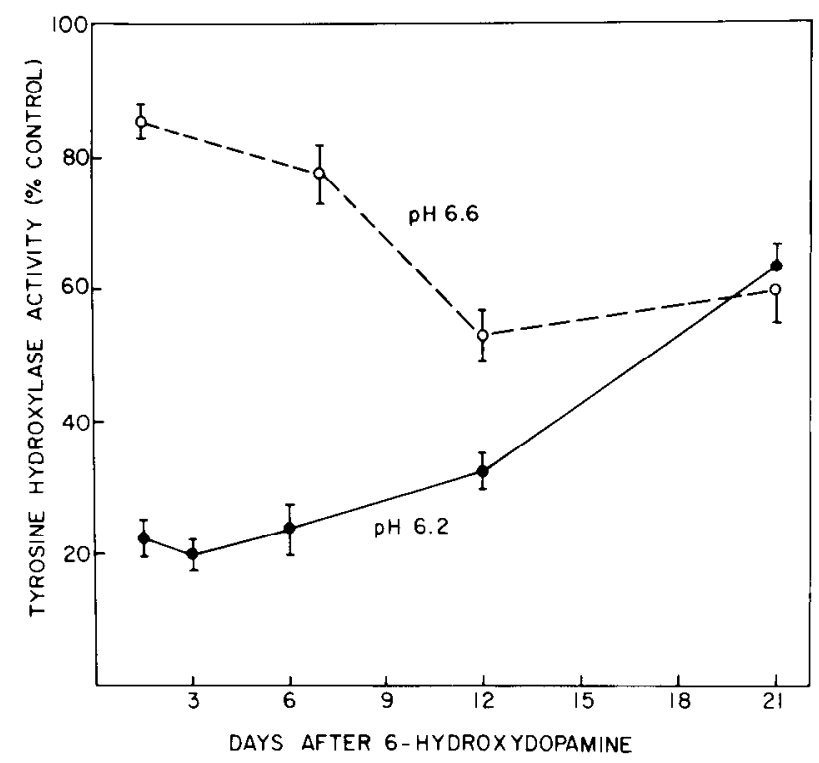

Figure 4. Hippocampal TH activity as a function of time after 6 HDA treatment. TH activity was measured in the pres-

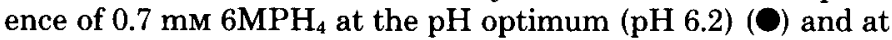
a "suboptimal" $\mathrm{pH}$ value ( $\mathrm{pH}$ 6.6) (O) $36 \mathrm{hr}$ to 21 days after 6HDA administration. Data are expressed as a percentage of control values (control values: $\mathrm{pH} 6.2,6.55 \pm 0.20$; $\mathrm{pH} 6.6,2.47$ $\pm 0.07 \mathrm{pmol} / \mathrm{mg} / \mathrm{min})$. Each point represents the mean $( \pm$ SEM) of four animals.
TABLE III

Hippocampal $6 \mathrm{MPH}_{4}$ kinetics 5 or 21 days after $6 \mathrm{HDA}$ lesions ${ }^{a}$

\begin{tabular}{|c|c|c|c|c|}
\hline & $K_{m}$ & $\begin{array}{c}\% \\
\text { Control }\end{array}$ & $V_{\max }$ & $\begin{array}{c}\% \\
\text { Control }\end{array}$ \\
\hline & $m M$ & & $\mathrm{pmol} / \mathrm{mg} / \mathrm{min}$ & \\
\hline Control & $1.11 \pm 0,20$ & 100 & $9.48 \pm 0.53$ & 100 \\
\hline $\begin{array}{l}5 \text { days } \\
\text { post- } 6 \mathrm{HDA}\end{array}$ & $0.50 \pm 0.19$ & 45.0 & $1.54 \pm 0.09$ & 16.2 \\
\hline $\begin{array}{l}21 \text { days } \\
\text { post- } 6 \mathrm{HDA}\end{array}$ & $1.32 \pm 0.17$ & 118.9 & $6.28 \pm 0.26$ & 66.2 \\
\hline
\end{tabular}

${ }^{a}$ Animals received an intraventricular injection of $6 \mathrm{HDA}(250 \mu \mathrm{g})$ and were killed 5 or 21 days later. Control animals were untreated. TH activity was measured in the presence of varying concentrations of $6 \mathrm{MPH}_{4}$ in Tris/acetate buffer, $\mathrm{pH}$ 6.2. Data subsequently were subjected to a kinetic analysis (see "Materials and Methods"). Values represent the mean \pm SEM for five separate animals. Note that this analysis was carried out at the $\mathrm{pH}$ optimum for control enzyme, thus minimizing the change in the $K_{m}$ at 5 days post-lesion (compare with Fig. 3).

TABLE IV

Norepinephrine content and tyrosine hydroxylase activity in hippocampus 7 and 21 days after the administration of $6 H D A$ to rats protected with desmethylimipramine ${ }^{a}$

\begin{tabular}{lccc}
\hline & \multirow{2}{*}{ NE Content } & \multicolumn{2}{c}{ Tyrosine Hydroxylase Activity ${ }^{b}$} \\
\cline { 2 - 4 } & & $\mathrm{pH} 6.2$ & $\mathrm{pH} 6.6$ \\
\hline \multirow{3}{*}{ Control } & $0.48 \pm 0.06$ & $6.41 \pm 0.38$ & $2.66 \pm 0.18$ \\
& & & \\
$6 \mathrm{HDA}$ & & & \\
7 days & $0.51 \pm 0.07$ & $6.38 \pm 0.30$ & $2.71 \pm 0.20$ \\
21 days & $0.47 \pm 0.07$ & $6.55 \pm 0.23$ & $2.68 \pm 0.15$ \\
\hline
\end{tabular}

${ }^{a}$ Animals received an intraventricular injection of $6 \mathrm{HDA}(250 \mu \mathrm{g})$ or saline vehicle $30 \mathrm{~min}$ after the intraperitoneal administration of desmethylimipramine $(25 \mathrm{mg} / \mathrm{kg}$ ). (This treatment was designed to protect noradrenergic terminals from the neurotoxic effects of $6 \mathrm{HDA}$; see "Results.") Control values from animals lesioned $36 \mathrm{hr}$ or 21 days previously were not significantly different and were pooled. All values are the mean \pm SEM for four animals (6HDA-treated) or for eight animals (controls).

${ }^{b} \mathrm{TH}$ activity was measured at the $\mathrm{pH}$ optimum (6.2) and at a suboptimal $\mathrm{pH}(6.6)$ in the presence of $0.7 \mathrm{mM}_{6} \mathrm{MPH}_{4}$.

tion of 6HDA. This procedure appears to inhibit selectively the high affinity NE transport system of noradrenergic terminals, thereby protecting them from the neurotoxin (Breese and Traylor, 1971). Animals treated in this way showed no decline in hippocampal NE content (although DA levels in striatum were reduced by $72 \%$ ). Moreover, hippocampal TH activity was not altered significantly either 7 or 21 days later (Table IV).

Effect of phosphorylating conditions on hippocampal TH activity from control and 6HDA-treated animals. Incubation of TH under cAMP-dependent protein-phosphorylating conditions results in an increase in the affinity of the enzyme for cofactor and a change in the shape of the $\mathrm{pH}$ curve (Goldstein et al., 1976; Murrin et al., 1976; Hegstrand et al., 1979). Our results suggested that, at early times after 6HDA treatment, hippocampal TH was activated in a similar manner. Therefore, we compared directly the effects of in vitro phosphorylating conditions and $6 \mathrm{HDA}$ pretreatment on TH activity. Enzyme activity was measured in the presence of a subsa- 

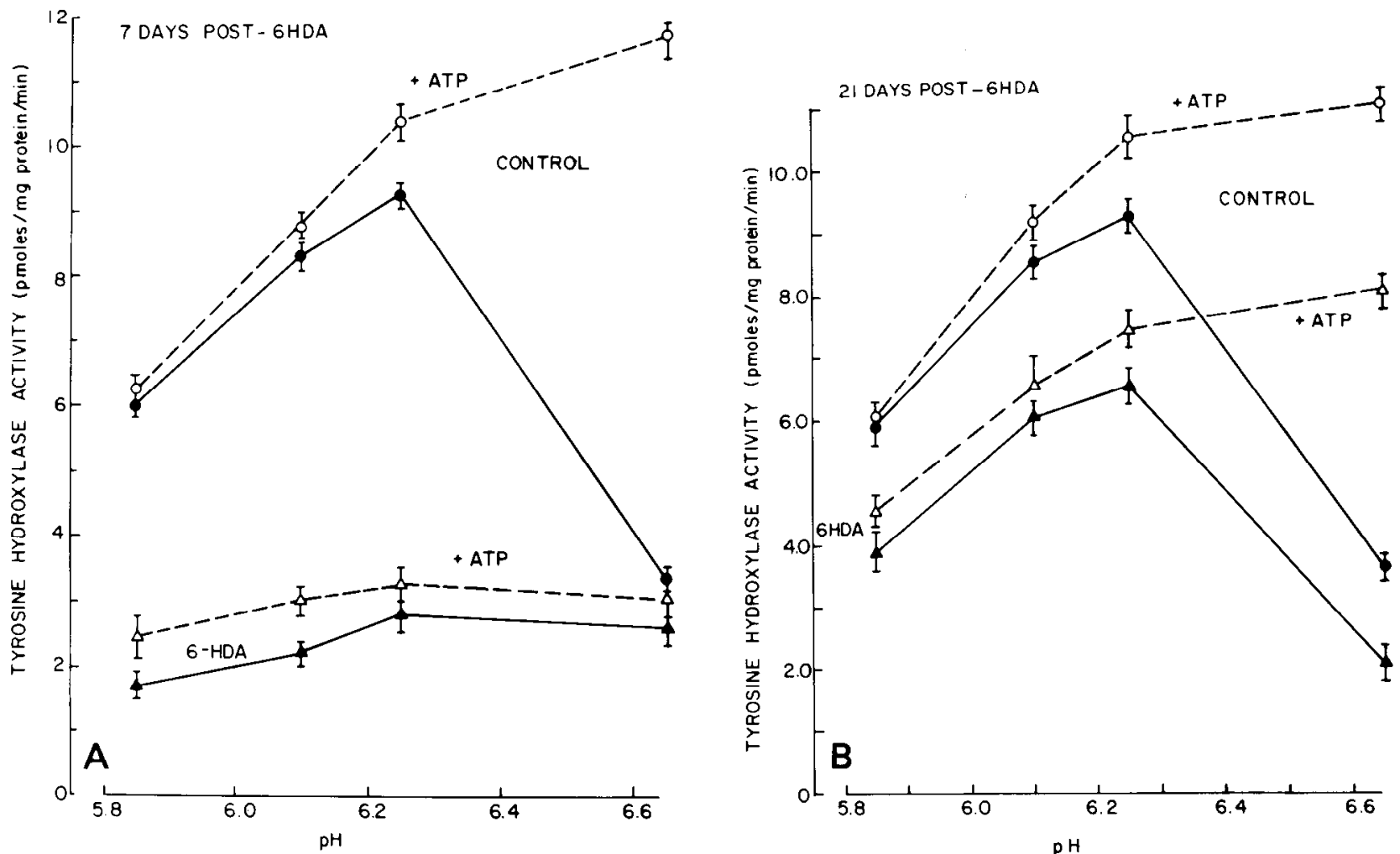

Figure 5. Effect of phosphorylating conditions on hippocampal TH activity, as a function of pH, 7 and 21 days after $6 \mathrm{HDA}$ administration. TH from control or $6 \mathrm{HDA}$-treated animals was preincubated under phosphorylating conditions (see "Materials and Methods"), following which, TH activity was measured in Tris/acetate buffer at various $\mathrm{pH}$ values in the presence of $1.5 \mathrm{mM}$ $6 \mathrm{MPH}_{4}$. Each point represents the mean ( \pm SEM) of five animals. Data are expressed as picomoles of $\mathrm{CO}_{2}$ released per mg of protein per min. $A, 7$ days post-6HDA, phosphorylating conditions did not significantly increase TH activity from $6 \mathrm{HDA}$-treated animals at any $\mathrm{pH}$ value examined, in contrast to their effect on control enzyme activity, which was most pronounced at pH values above the $\mathrm{pH}$ optimum (pH 6.65). $\mathrm{B}, 21$ days post-6HDA, phosphorylating conditions increased both control and $6 \mathrm{HDA}$ treated enzyme activity in an identical manner.

turating cofactor concentration as a function of assay $\mathrm{pH}$.

Control hippocampal tissue preincubated under phosphorylating conditions was compared with hippocampal tissue from animals lesioned 7 days previously with 6HDA. As before, control TH exhibited a pH optimum of 6.2 , while $\mathrm{TH}$ from recently lesioned animals showed no such optimum. The shape of this latter curve closely resembled that of control TH incubated under phosphorylating conditions. Moreover, preincubating tissue from the lesioned animals under phosphorylating conditions had no significant effect on enzyme activity at any pH examined (Fig. 5A). In contrast, phosphorylating conditions increased hippocampal TH activity 21 days after $6 \mathrm{HDA}$ in a manner which appeared identical to the effect on control enzyme activity (Fig. $5 B$ ).

TH activity in locus coeruleus as a function of time after 6HDA treatment. In addition to the apparent activation of hippocampal TH at early time points, we observed an increase in TH activity, at $\mathrm{pH} 6.2,21$ days postoperative. This latter change could be due to the delivery of additional $\mathrm{TH}$ molecules to this terminal field from the cell bodies of origin in the locus coeruleus. If so, then it might be preceded by an increase in the amount of TH protein in those cells. Therefore, we examined TH in locus coeruleus at several times after 6HDA treatment. $\mathrm{TH}$ activity was assayed at $\mathrm{pH} 6.2$, a value within the optimal range for TH in these cells (Fig. 1). We observed that TH activity had increased to $210 \%$ of control by 5 to 7 days after 6HDA (Fig. 6) and was accompanied by a $165 \%$ increase in $\mathrm{TH}$ protein as determined by immunoinhibition (Fig. 7). By 21 days, the increase in TH had disappeared and TH was actually somewhat below control levels as determined by both direct assay (Fig. 6) and immunoinhibition (Fig. 7).

Time course of $6 H D A$-induced changes in cerebellar TH activity measured under optimal and suboptimal assay conditions. The above results are consistent with the hypothesis that the gradual increase in hippocampal $\mathrm{TH}$ activity results from an increase in the amount of TH protein provided by the cell bodies. A further prediction from that hypothesis is that the delay between the increase in the number of active molecules in the cell bodies and the apparent increase in residual nerve terminals will be determined by the distance of those terminals from the locus coeruleus. Therefore, we examined the time course of $6 \mathrm{HDA}$-induced alterations in $\mathrm{TH}$ activity in cerebellum, a brain area which also receives noradrenergic input from locus coeruleus but is located much closer to those cells (Fuxe, 1965).

$\mathrm{TH}$ activity was measured at $\mathrm{pH} 6.1$, the $\mathrm{pH}$ optimum for TH from this structure (Fig. 1). Thirty-six hours after 6HDA treatment, we observed a decrease in NE content to $38 \%$ of control and in TH activity to $43 \%$ of control, an 


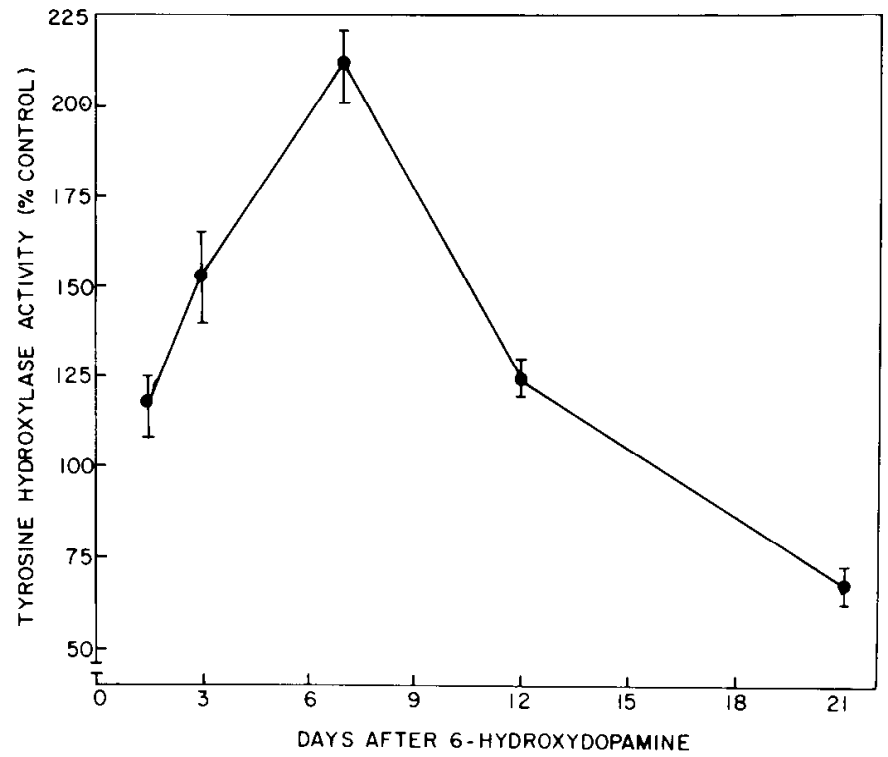

Figure 6. Time course of changes in locus coeruleus TH activity following $6 \mathrm{HDA}$ administration. TH activity was measured $36 \mathrm{hr}$ or 21 days after $6 \mathrm{HDA}$ treatment. The assay was carried out in Tris/acetate buffer, $\mathrm{pH} 6.2$, in the presence of 3.0 $\mathrm{mM} 6 \mathrm{MPH}_{4}$. Data are expressed as a percentage of control values (average control value: $2.43 \pm 0.21 \mathrm{pmol} / \mathrm{pair} / \mathrm{min}$ ). Each point represents the mean $( \pm \mathrm{SEM})$ of at least three animals.

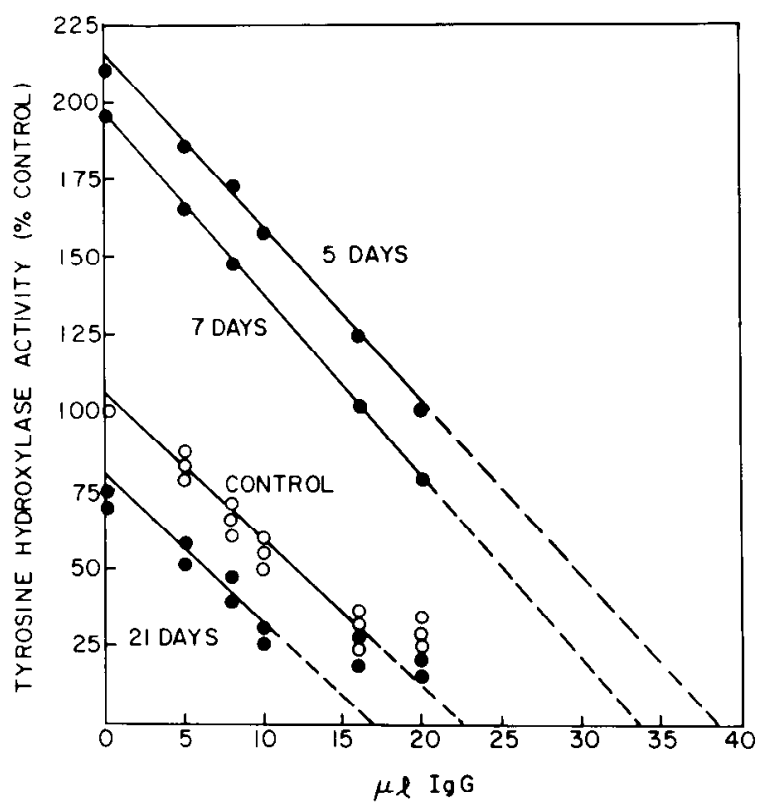

Figure 7. Amount of immunoreactive TH in locus coeruleus 5 to 21 days after $6 \mathrm{HDA}$ treatment. TH activity was measured in locus coeruleus in control animals $(O)$ and 5,7 , or 21 days after 6HDA administration $(O)$ in the presence of varying concentrations of a specific TH antibody (see "Materials and Methods"). The assay was carried out in Tris/acetate buffer, $\mathrm{pH} 6.2$, in the presence of $3.0 \mathrm{~mm} 6 \mathrm{MPH}_{4}$. Data are expressed as a percentage of control TH activity (average control value: $2.77 \pm 0.27 \mathrm{pmol} / \mathrm{pair} / \mathrm{min})$. The equivalence point was determined for each time point by extrapolation. The similarity of the slopes of each extrapolated line was interpreted as indicating that the affinity of the antibody for the enzyme was not altered by 6 HDA treatment at any of the time points examined. Each point represents the average of three replicates. effect comparable to that obtained with hippocampus. However, in contrast to hippocampus, cerebellar TH activity had increased already to a new steady state level (74\% control) by day 7 . We also measured TH activity at a suboptimal pH ( $\mathrm{pH}$ 6.5). Under these conditions, TH activity had increased to $133 \%$ of control $36 \mathrm{hr}$ after 6HDA (Fig. 8), suggesting an activation of $\mathrm{TH}$ similar to that observed in hippocampus. This effect had decreased by 5 to 7 days after the lesion (Fig. 8).

Effect of varying lesion size on THI activity in cerebellum and locus coeruleus. If the gradual increase in TH activity measured under optimal assay conditions represents an adaptive response to the lesion-induced decrease in receptor activation, then the extent of the increase should be proportional to the size of the lesion. To examine the relationship between lesion size and $\mathrm{TH}$ activity, animals were given different doses of $6 \mathrm{HDA}$ and killed 5 to 21 days later, times when the apparent increase in the amount of $\mathrm{TH}$ in cerebellum was at or near maximum. Cerebellar TH was assayed in the presence of a saturating concentration of $6 \mathrm{MPH}_{4}$. We observed that, in 6HDA-lesioned animals, TH activity was significantly higher than the value predicted from the NE content of the structure. Moreover, the extent of the deviation increased with increasing lesion size (Fig. 9A). This phenomenon is seen most clearly when TH activity is expressed as a ratio of enzyme activity to NE content, a possible index of the amount of enzyme per residual terminal. This ratio was increased 2- to 3-fold in animals with NE depletions of 60 to $80 \%$. Larger NE depletions were accompanied by still greater increases in the ratio (Fig. 9B).

We also examined the effect of different sized lesions on NE content and TH activity in locus coeruleus 5 days

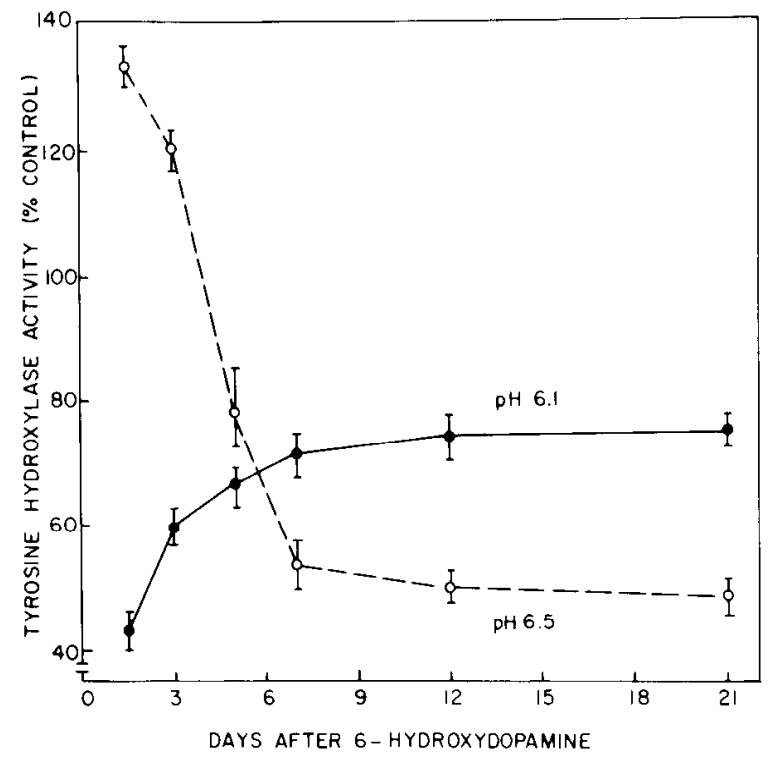

Figure 8. Cerebellar TH activity as a function of time after 6HDA treatment. TH activity was measured in cerebellum in the presence of $0.7 \mathrm{mM}^{6} \mathrm{MPH}_{4}$ at the $\mathrm{pH}$ optimum $(\mathrm{pH}$ 6.1) (O) and at a "suboptimal" $\mathrm{pH}$ value $(\mathrm{pH} \mathrm{6.5)}$ (O) $36 \mathrm{hr}$ to 21 days after $6 \mathrm{HDA}$ administration. Data are expressed as a percentage of control values (average control values: $\mathrm{pH} 6.1,4.33$ $\pm 0.15 ; \mathrm{pH} 6.5,1.73 \pm 0.12 \mathrm{pmol} / \mathrm{mg} / \mathrm{min})$. Each point represents the mean ( \pm SEM) of four animals. 

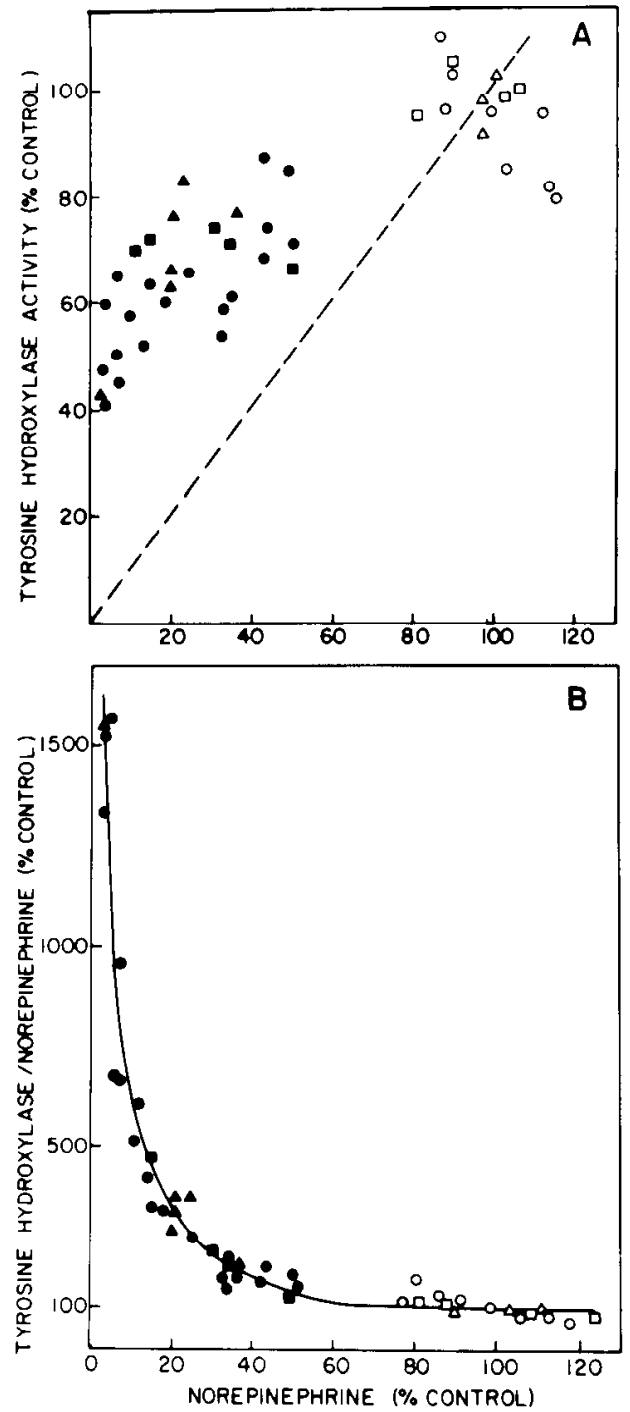

Figure 9. Effect of varying lesion size on cerebellar $\mathrm{TH}$ activity 5 to 21 days after $6 \mathrm{HDA}$ administration. Animals were given 175,200 , or $250 \mu \mathrm{g}$ of $6 \mathrm{HDA}$ or two doses of $250 \mu \mathrm{g}$ of 6HDA 15 min apart. Cerebellar TH activity and NE levels then were assayed 5,12 , or 21 days later. TH activity was measured in Tris/acetate buffer, $\mathrm{pH} 6.2$, in the presence of $3.0 \mathrm{mM}_{6} \mathrm{MPH}_{4}$. Each point represents data from a single animal (average of three replicates). $A$, Data are expressed as a percentage of control values (controls: 5 days, $O ; 12$ days, $\triangle ; 21$ days, $\square$. 6HDA: 5 days, $\mathbf{O}$; 12 days, $\Delta ; 21$ days, $\square$ ). The dashed line represents the relationship that would be predicted if both $\mathrm{TH}$ activity and NE levels were decreased to the same extent by the lesion. The deviation of the data points from this line was interpreted as indicating that the amount of $\mathrm{TH}$ in residual neurons following $6 \mathrm{HDA}$ treatment was greater than the amount of TH in control nerve terminals. $B$, Data are expressed as a ratio of $\mathrm{TH}$ activity (percentage of control) to $\mathrm{NE}$ levels (percentage of control). This ratio was interpreted as being an index of the amount of $\mathrm{TH}$ per residual nerve terminal, which increased as the NE depletion became larger. Symbols are the same as those in $A$.

post-lesion, a time when the 6HDA-induced increase in the number of active TH molecules was maximal (see above). As the dose of 6HDA increased, so did the magnitude of the destruction of nerve terminals as indi-
TABLE V

Tyrosine hydroxylase activity in locus coeruleus as a function of lesion size

\begin{tabular}{|c|c|c|c|}
\hline \multirow[b]{2}{*}{ Treatment $(N)$} & \multirow{2}{*}{$\begin{array}{c}\text { Cerebellum } \\
\text { NE } \\
\text { Content }\end{array}$} & \multicolumn{2}{|c|}{ Locus Coeruleus } \\
\hline & & $\begin{array}{c}\text { TH } \\
\text { Activity }\end{array}$ & $\begin{array}{c}\text { NE } \\
\text { Content }\end{array}$ \\
\hline & $\mu g / g m$ & pmol/pair/min & $\mu g / p a i r$ \\
\hline Control (4) & $0.19 \pm 0.01$ & $2.70 \pm 0.24$ & $47.7 \pm 4.0$ \\
\hline \multicolumn{4}{|l|}{ 6IIDA } \\
\hline $175 \mu \mathrm{g}(3)$ & $0.09 \pm 0.01$ & $4.14 \pm 0.31^{b}$ & $50.4 \pm 3.1$ \\
\hline $200 \mu \mathrm{g}(3)$ & $0.07 \pm 0.01$ & $5.40 \pm 0.37^{b}$ & $47.8 \pm 3.9$ \\
\hline $250 \mu \mathrm{g}(5)$ & $0.04 \pm 0.01$ & $4.82 \pm 0.32^{b}$ & $49.8 \pm 3.4$ \\
\hline $2 \times 250 \mu \mathrm{g}(3)$ & $0.008 \pm 0.002$ & $2.89 \pm 0.16$ & $40.8 \pm 1.3$ \\
\hline
\end{tabular}

${ }^{a}$ Animals received an intraventricular injection of $6 \mathrm{HDA}$ or saline vehicle and were sacrificed 5 days later. NE was measured in cerebellum to assess the degree of terminal field damage. TH activity was measured at an optimal $\mathrm{pH}(6.2)$ in the presence of $3 \mathrm{mM} 6 \mathrm{MPH}_{4}$. All values represent the mean $\pm \mathrm{SEM}$.

"Significantly different from control $(p<0.01)$.

cated by measurement of cerebellar NE levels (Table V). However, there was no loss of NE in the locus coeruleus area and, thus, presumably no damage to cell bodies, except at the highest dose of 6HDA (two injections of $250 \mu \mathrm{g}$ of $6 \mathrm{HDA}$ ). TH activity in locus coeruleus increased following $6 \mathrm{HDA}$ treatment. Yet, in contrast to the steadily increasing ratio of TH to NE observed in the cerebellum, there appeared to be a maximum to the increase in $\mathrm{TH}$ activity in locus coeruleus (Table V). In fact, following the largest lesions, no increase in $\mathrm{TH}$ activity was observed. This could not be accounted for by the loss of NE.

\section{Discussion}

TH is localized specifically within catecholaminergic neurons where it catalyzes the rate-limiting step in catecholamine biosynthesis, the hydroxylation of phenylalanine and tyrosine to DOPA (Nagatsu et al., 1964; Pickel et al., 1975). It was to be expected, therefore, that the 6HDA-induced degeneration of NE-containing neurons in brain would decrease $\mathrm{TH}$ activity within previously innervated tissue. However, we now have presented evidence to suggest that, following such lesions, the decrease in TH activity is significantly less than that predicted from the apparent loss of terminals, suggesting an actual increase in TH activity per residual terminal. This increase appears to result from two temporally distinct events. First, there is a rapid activation of existing enzyme, which seems to be associated with an increased affinity for cofactor. This is followed by a more gradual increase in the apparent $V_{\max }$ of the enzyme, possibly associated with an increase in the number of enzyme molecules.

Short term activation of TH. Thirty-six hours after the intraventricular administration of $250 \mu \mathrm{g}$ of $6 \mathrm{HDA}$, the concentration of NE in the hippocampus was decreased to 20 to $25 \%$ of control, where it remained for at least 21 days. (In other studies, we have observed no restoration of $\mathrm{NE}$ content for at least 76 days (Acheson et al., 1980).) A similar decline in the rate of in vitro high affinity NE uptake (Acheson et al., 1980) and in the 
apparent $V_{\max }$ for TH (see "Results") was seen also. In contrast, the NE content of the locus coeruleus was unaltered. These results suggested that $6 \mathrm{HDA}$ had destroyed most of the terminals of the locus coeruleushippocampus projection, while leaving the cell bodies intact. However, these changes were accompanied by a marked activation of residual TH in the terminal region, as measured by the enzyme's $\mathrm{pH}$ optimum and its affinity for cofactor. As a result, soluble hippocampal TH activity measured under subsaturating cofactor concentrations and at a suboptimal $\mathrm{pH}$ was decreased only slightly.

DA receptor antagonists produce a similar activation of TH in the striatum (Zivkovic et al., 1974; Lovenberg and Bruckwick, 1975). It has been hypothesized that these drugs act by blocking an inhibitory feedback loop normally activated by $\mathrm{DA}$ and thereby triggering an increase in impulse flow which somehow alters the affinity of TH for cofactor. This hypothesis is supported by a variety of data including independent evidence for negative feedback (Farnebo and Hamberger, 1971; Groves et al., 1975; Giorguieff et al., 1976), measurements of increased impulse flow and DA metabolism in the dopaminergic nigrostriatal system after administration of DA antagonists (Carlsson and Lindqvist, 1963; Bunney et al., 1973), and activation of TH by direct electrical stimulation of DA cells (Murrin et al., 1976).

Negative feedback loops regulating activity in locus coeruleus cells have been described also (Cedarbaum and Aghajanian, 1976). Moreover, increased firing of these cells, like those of the substantia nigra, appears to activate TH (Roth et al., 1974). Thus, by decreasing the availability of NE, 6HDA may reduce the effectiveness of these circuits, increase impulse flow in intact axons, and activate residual $\mathrm{TH}$ molecules. In support of this hypothesis, we recently have observed a 3- to 4-fold increase in firing rate in locus coeruleus cells after 6HDA (L. A. Chiodo and M. J. Zigmond, unpublished observations).

Our results indicate that TH activity can no longer be increased by cAMP-dependent protein-phosphorylating conditions at these early postoperative times. Thus, it is possible that the changes in the affinity of the enzyme for cofactor after 6HDA are due to a phosphorylationinduced change in the conformation of the enzyme. However, similar changes in TH activity can be produced by other means as well (Kuczenski and Mandell, 1972; Lloyd and Kaufman, 1974). Moreover, in preliminary studies, we observed that the activation of hippocampal TH by phosphorylating conditions was reduced by $55 \%$ of control by a $30-\mathrm{min}$ preincubation at $37^{\circ} \mathrm{C}$, presumably due to the action of endogenous phosphatases. In contrast, lesion-induced activation was reduced by only $20 \%$ of control. Thus, a determination of the precise mechanism of these changes must await further experimentation.

Long term activation of $T H$. Despite the permanence of the decline in NE, the apparent $V_{\max }$ for $\mathrm{TH}$ increased over a period of several days or weeks, an observation consistent with our previous findings (Acheson et al., 1980 ). In contrast to the initial activation of $\mathrm{TH}$, we believe that this increase in $\mathrm{TH}$ activity represents an increase in the number of active $\mathrm{TH}$ molecules: It is detectable despite a saturating cofactor concentration and at the $\mathrm{pH}$ optimum, it appears gradually, it is not associated with a change in the $\mathrm{pH}$ dependence of the enzyme, and it does not preclude the ability of phosphorylating conditions to increase further enzyme activity.

We believe that the gradual rise in hippocampal TH is occurring in central noradrenergic terminals. Innervation of hippocampus by peripheral noradrenergic fibers occurs following certain types of lesions (e.g., Loy and Moore, 1977). However, we find that our results are unaffected by removal of the superior cervical ganglion which contains the cell bodies of origin for the sympathetic innervation of the brain (Acheson et al., 1980). Moreover, the increase in $\mathrm{TH}$ which we observed is not accompanied by an increase in the NE content of the tissue as would be expected by an increased innervation. Likewise, the increased TH activity probably is not due to increased innervation from central DA fibers, since we have observed no rise in the DA content of hippocampus after $6 \mathrm{HDA}$.

The elevation in TH activity in the terminals measured under saturating conditions could result from at least two types of events, an increase in the $V_{\max }$ of existing enzyme molecules or an increase in the total number of molecules, due either to an increase in enzyme synthesis, decreased degradation, or simply a channeling of $\mathrm{TH}$ molecules formed at a normal rate into fewer terminals. While an increased $V_{\max }$ of existing molecules has been reported (Lewander et al., 1977; Iuvone et al., 1979), we believe that an increase in the total number of $\mathrm{TH}$ molecules per terminal can best explain the data presented here for two reasons. First, the increased TH activity appears more quickly in terminal areas near the locus coeruleus than in those areas farther away. This is consistent with a role for axonal transport in delivering additional $\mathrm{TH}$, although the actual time delays are longer than predicted from most estimates of the rate of TH transport (Levin, 1978). (Perhaps the transport system is damaged even in otherwise intact neurons.) Secondly, the increases in TH activity in terminal areas are preceded by an increase in the cell body region. The latter effect could be caused by a temporary pile-up of $\mathrm{TH}$ due to damaged axons, as has been proposed in the case of the transient increase in $\mathrm{TH}$ activity seen in locus coeruleus after transection of the rostralward axons from that area (Ross et al., 1975). However, our observation that TH activity in the cell body region does not continue to rise with increasing loss of $\mathrm{NE}$ terminals suggests that the level of $\mathrm{TH}$ activity in the cells is being limited, at least in part, by some active process, such as TH protein synthesis.

Long term elevations in TH activity in residual catecholaminergic cells within a damaged system have been reported before. For example, increased enzyme activity has been observed in adrenal medulla after destruction of peripheral noradrenergic terminals (Thoenen et al., 1969) and in the locus coeruleus after contralateral locus coeruleus destruction (Buda et al., 1975). We have reported an analogous increase in the ratio of TH activity to catecholamine content in the striatum after $6 \mathrm{HDA}$ (Acheson et al., 1979), and similar results have been reported for the basal ganglia in Parkinson's disease (Lloyd et al., 1975). Finally, an examination of some of the earlier reports regarding the impact of $6 \mathrm{HDA}$ on 
brain reveals several instances of a decline in catecholamine content which was more severe than the decline in TH activity (e.g., Iversen and Uretsky, 1970).

There are several similarities between these long term changes in TH activity after 6HDA and the effects of reserpine on $\mathrm{TH}$ activity within the same neuronal system. The loss of NE stores caused either by degeneration (6HDA) or destruction of storage vesicles (reserpine, results in an increase in $\mathrm{TH}$ activity in locus coeruleus followed by a delayed increase in $\mathrm{TH}$ activity in terminal fields, with the increases appearing more slowly in more distant regions (Black, 1975; R. E. Zigmond, 1979). Analogous effects have been observed in the peripheral autonomic nervous system using reserpine or the long acting $\alpha$-adrenergic antagonist, phenoxybenzamine (Thoenen et al., 1970). In each case, the effects appear to result from an increase in the amount of TH protein (Mueller et al., 1969; Reis et al., 1975).

It has been suggested that these changes, like the short term changes discussed above, result from the disruption of an inhibitory influence normally exerted by $\mathrm{NE}$ on transmitter release. In the case of these long term changes, the feedback loop is presumed to be a multineuronal pathway and the final influence is thought to be exerted on noradrenergic cell bodies via trans-synaptic input. Support for this hypothesis has been provided recently by the observation that electrical stimulation of the preganglionic input to the superior cervical ganglion increases the amount of TH in the ganglion cells (R. E. Zigmond and Chalazonitis, 1979). Such a mechanism might explain the failure of locus coeruleus $\mathrm{TH}$ activity to increase following the largest lesion, since, at least in the periphery, extensive damage to noradrenergic terminal fields causes a pulling away of afferent endings from NE cells (Purves, 1975) which would abolish transsynaptic input.

Functional implications of the changes in TH activity. It remains to be demonstrated that the changes in $\mathrm{TH}$ activity which we have reported here have important functional significance to the lesioned animals. Such significance would require, first, that the increase in $\mathrm{TH}$ activity be accompanied by a parallel increase in NE release. Secondly, the increase in NE release must alter target cell activity in order to offset the impact of the lesion.

The first assumption is consistent with several observations: The activation of striatal TII produced by neuroleptics is accompanied by an increase in DA turnover in vivo (Bunney et al., 1973; Keller et al., 1973) and in the depolarization-induced stimulation of DA synthesis in vitro (M. Petrus and M. J. Zigmond, unpublished observations). In addition, increased DA turnover in residual neurons accompanies the long term changes in TII activity observed in strialum after 6HDA (Acheson et al., 1979; see also Agid et al., 1973; Hefti et al., 1980). Finally, an increase in NE turnover in neurons spared by the lesion is consistent with our preliminary observation of increased firing rate in locus coeruleus cells and would explain the failure of $\mathrm{NE}$ levels to increase in parallel with the increases in TH activity.

It is less clear, however, that the additional NE made available by increased $\mathrm{TH}$ activity in remaining terminals would serve to compensate for the lost terminals. For such a "functional re-innervation" of denervated target cells to take place, NE released by one nerve terminal would be required to gain access to cells normally innervated by another. Moreover, these new interactions would have to substitute for the original synaptic events. These are not conventional assumptions for the mammalian nervous system. Nonetheless, such a "hormonal" mode of action is consistent with the diffuse nature of the anatomical organization of the noradrenergic locus coeruleus system (Ungerstedt, 1971b) located within the classically defined brainstem reticular formation (Moore, 1980) and with many of the functions attributed to the locus coeruleus system (Amaral and Sinnamon, 1977). Moreover, whatever the size of the normal field of influence of a noradrenergic terminal, this should be increased by the proposed elevation in transmitter release and further accentuated by two other effects of $6 \mathrm{HDA}$, a reduction in the availability of the high affinity uptake sites which normally serve to inactivate $\mathrm{NE}$ and an increase in the presence of postsynaptic NE receptors (Sporn et al., 1977; U'Prichard et al., 1979).

In conclusion, we have presented evidence to suggest that, following subtotal destruction of central noradrenergic terminals with $6 \mathrm{HDA}$, there is a rapid increase in the activity of the rate-limiting enzyme, $\mathrm{TH}$, within residual terminals. This appears to be due to an initial activation of existing enzyme molecules followed by a gradual increase in the number of active molecules. These events may serve an important compensatory function in maintaining a noradrenergic influence on target cells within the CNS.

\section{References}

Acheson, A. L., M. J. Zigmond, and E. M. Stricker (1979) Tyrosine hydroxylase and DOPAC in striatum after 6-hydroxydopamine. Trans. Am. Soc. Neurochem. 10: 142.

Acheson, A. L., M. J. Zigmond, and E. M. Stricker (1980) Compensatory increase in tyrosine hydroxylase activity in rat brain after intraventricular injections of 6-hydroxydopamine. Science 207: 537-540.

Acheson, A. L., G. Kapatos, and M. J. Zigmond (1981) The effects of phosphorylating conditions on tyrosine hydroxylase activity are influenced by assay conditions and brain region. Life Sci. 28: 1407-1420.

Agid, Y., F. Javoy, and J. Glowinski (1973) Hyperactivity of remaining dopaminergic neurons after partial destruction of the nigro-striatal dopaminergic system in the rat. Nature New Biol. 245: 150-151.

Amaral, D. G., and H. M. Sinnamon (1977) The locus coeruleus: Neurobiology of a central noradrenergic nucleus. Prog. Neurobiol. 9: 147-196.

Barnes, J. E., and A. J. Waring (1980) Pocket Programmable Calculators in Biochemistry, pp. 204-224, John Wiley \& Sons, New York.

Black, I. R. (1975) Increased tyrosine hydroxylase activity in frontal cortex and cerebellum after reserpine. Brain Res. 95: 170-176.

Breese, G. R., and T. D. Traylor (1971) Depletion of brain noradrenaline and dopamine by 6 -hydroxydopamine. Br. J. Pharmacol. 42: 88-99.

Buda, M., B. Roussel, B. Renaud, and J. F. Pujol (1975) Increase in tyrosine hydroxylase activity in the locus coeruleus of the rat brain after contralateral lesioning. Brain Res. 93: 564-569. 
Bunney, B. S., J. R. Walters, R. H. Roth, and G. K. Aghajanian (1973) Dopaminergic neurons: Effect of antipsychotic drugs and amphetamine on single cell activity. J. Pharmacol. Exp. Ther. 185: 560-568.

Carlsson, A., and M. Lindqvist (1963) Effect of chlorpromazine and haloperidol on formation of 3-methoxytyramine and normetanephrine in mouse brain. Acta Pharmacol. Toxicol. (Copenh.) 20: 140-144.

Cedarbaum, J. M., and G. K. Aghajanian (1976) Noradrenergic neurons of the locus coeruleus: Inhibition by epinephrine and activation by the $\alpha$-antagonist piperoxane. Brain Res. 112: 413-419.

Farnebo, L. O., and B. Hamberger (1971) Drug-induced changes in the release of ${ }^{3} \mathrm{H}$-monoamines from field stimulated rat brain slices. Acta. Physiol. Scand. Suppl. 371: 34-44.

Fuxe, K. (1965) Evidence for the existence of monoamine neurons in the central nervous system. II. The distribution of monoamine terminals in the central nervous system. Acta Physiol. Scand. Suppl. 247, 64: 37-84.

Gauthier, P., R. A. Nadeau, and J. deChamplain (1972) Acute and chronic cardiovascular effects of 6-hydroxydopamine in dogs. Circ. Res. 31: 207-217.

Giorguieff, M. F., M. L. LeFloch, T. C. Westfall, J. Glowinski, and M. J. Besson (1976) Nicotinic effect of acetylcholine on the release of newly synthesized ${ }^{3} \mathrm{H}$-dopamine in rat striatal slices and cat caudate nucleus. Brain Res. 106: 117-131.

Goldstein, M., R. L. Bronaugh, B. Ebstein, and C. Roberge (1976) Stimulation of tyrosine hydroxylase activity by cyclic AMP in synaptosomes and in soluble striatal enzyme preparations. Brain Res. 109: 563-574.

Groves, P., C. J. Wilson, S. J. Young, and G. V. Rebec (1975) Self-inhibition by dopaminergic neurons. Science 100: 522529.

Hedreen, J. (1975) Increased nonspecific damage after lateral ventricle injection of 6-OHDA compared with fourth ventricle injection in rat brain. In Chemical Tools in Catecholamine Research, G. Jonsson, T. Malmfors, and C. Sachs, eds., Vol. I., pp. 91-100, North-Holland Publishing Co., Amsterdam.

Hefti, F., E. Melamed, and R. J. Wurtman (1980) Partial lesions of the dopaminergic nigrostriatal system in rat brain: Biochemical characterization. Brain Res. 195: 123-138.

Hegstrand, L. R., J. R. Simon, and R. H. Roth (1979) Tyrosine hydroxylase: Examination of conditions influencing activity in pheochromocytoma, adrenal medulla, and striatum. Biochem. Pharmacol. 28: 519-523.

Iuvone, P. M., T. H. Joh, and N. H. Neff (1979) Regulation of retinal tyrosine hydroxylase: Long-term exposure to light increased the apparent $V_{\max }$ without a concomitant increase of immunotitratable enzyme molecules. Brain Res. 178: 191195.

Iversen, L. L., and N. J. Uretsky (1970) Regional effects of 6hydroxydopamine on catecholamine containing neurones in rat brain and spinal cord. Brain Res. 24: 364-367.

Joh, T. H., C. Geghman, and D. J. Reis (1973) Immunochemical demonstration of increased accumulation of tyrosine hydroxylase protein in sympathetic ganglia and adrenal medulla elicited by reserpine. Proc. Natl. Acad. Sci. U. S. A. 70: 27672771.

Jonsson, G. (1980) Chemical neurotoxins as denervation tools in neurobiology. Annu. Rev. Neurosci. 3: 169-187.

Kapatos, G., and M. J. Zigmond (1979) Effect of haloperidol on dopamine synthesis and tyrosine hydroxylase in striatal synaptosomes. J. Pharmacol. Exp. Ther. 208: 468-475.

Keller, H. H., G. Bartholini, and A. Pletscher (1973) Increase in 3-methoxy-4-hydroxyphenylethylene glycol in rat brain by neuroleptic drugs. Eur. J. Pharmacol. 23: 183-189.

Kuczenski, R. T., and A. J. Mandell (1972) Allosteric activation of hypothalamic tyrosine hydroxylase by ions and sulphated mucopolysaccharides. J. Neurochem. 19: 131-137.

Laverty, R., and K. Taylor (1970) Effects of intraventricular 2,4,5-trihydroxyphenylethylamine (6-hydroxydopamine) on rat behavior and brain catecholamine metabolism. Br. J. Pharmacol. 40: 836-846.

Levin, B. E. (1978) Axonal transport of $\left[{ }^{3} \mathrm{H}\right]$ proteins in a noradrenergic system of the rat brain. Brain Res. 150: 55-68.

Lewander, T., T. H. Joh, and D. J. Reis (1977) Tyrosine hydroxylase: Delayed activation in central noradrenergic neurons and induction in adrenal medulla elicited by stimulation of central cholinergic receptors. J. Pharmacol. Exp. Ther. 200: 523-534

Lloyd, T., and S. Kaufman (1974) The stimulation of partially purified bovine caudate tyrosine hydroxylase by phosphatidyl-L-serine. Biochem. Biophys. Res. Commun. 59: 12621269.

Lloyd, K. G., L. Davidson, and O. Hornykiewicz (1975) The neurochemistry of Parkinson's disease: Effect of L-DOPA therapy. J. Pharmacol. Exp. Ther. 195: 453-464.

Lovenberg, W., and E. A. Bruckwick (1975) Mechanisms of receptor mediated regulation of catecholamine synthesis in brain. In Pre- and Postsynaptic Receptors, E. Usdin and W. E. Bunney, eds., pp. 149-169, Marcel Dekker, New York.

Loy, R., and R. Y. Moore (1977) Anomalous innervation of the hippocampal formation by peripheral sympathetic axons following mechanical injury. Exp. Neurol. 57: 645-650.

Miyamoto, E., J. F. Kuo, and P. Greengard (1969) Cyclic nucleotide-dependent protein kinase. III. Purification and properties of $3^{\prime}, 5^{\prime}$-monophosphate-dependent protein kinase from bovine brain. J. Biol. Chem. 244: 6395-6402.

Moore, R. Y. (1980) The reticular formation: Monoamine neuron systems. In The Reticular Formation Revisited, J. A. Hobson and M. A. B. Brazier, eds., pp. 67-81, Raven Press, New York.

Mueller, R. A., H. Thoenen, and J. Axelrod (1969) Inhibition of trans-synaptically increased tyrosine hydroxylase activity by cycloheximide and actinomycin-D. Mol. Pharmacol. 5: 463469.

Murrin, L. C., V. H. Morgenroth, and R. H. Roth (1976) Dopaminergic neurons: Effects of electrical stimulation on tyrosine hydroxylase. Mol. Pharmacol. 12: 1070-1081.

Nagatsu, T., M. Levitt, and S. Udenfriend (1964) The initial step in norepinephrine biosynthesis. J. Biol. Chem. 239: 29102917.

Nielsen, K. H., V. Simonsen, and K. E. Lind (1962) Dihydropteridine reductase- $\mathrm{A}$ method for the measurement of activity and investigations of the specificity for $\mathrm{NADH}$ and NADPH. Eur. J. Biochem. 9: 497-502.

Pickel, V. M., T. H. Joh, and D. J. Reis (1975) Ultrastructural localization of tyrosine hydroxylase in noradrenergic neurons of brain. Proc. Natl. Acad. Sci. U. S. A. 72: 659-666.

Purves, D. (1975) Functional and structural changes in mammalian sympathetic neurons following interruption of their axons. J. Physiol. (Lond.) 252: 429-463.

Reis, D. J., T. H. Joh, and R. A. Ross (1975) Effects of reserpine on activities and amounts of tyrosine hydroxylase and dopamine- $\beta$-hydroxylase in catecholamine neuronal systems in rat brain. J. Pharmacol. Exp. Ther. 193: 775-784.

Ross, R. A., T. H. Joh, and D. J. Reis (1975) Reversible changes in the accumulation and activities of tyrosine hydroxylase and dopamine- $\beta$-hydroxylase in neurons of nucleus locus coeruleus during the retrograde reaction. Brain Res. 92: 5772

Roth, R. H., P. M. Salzman, and V. H. Morgenroth (1974) Noradrenergic neurons: Allosteric activation of hippocampal tyrosine hydroxylase by stimulation of the locus coeruleus. Biochem. Pharmacol. 23: 2779-2784. 
Saller, C. F., and M. J. Zigmond (1978) A radioenzymatic assay for catecholamines and dihydroxyphenylacetic acid. Life Sci. 23: $1117-1130$.

Simon, J. R., and R. H. Roth (1979) Striatal tyrosine hydroxylase: Comparison of the activation produced by depolarization and dibutyryl-cAMP. Mol. Pharmacol. 16: 224-233.

Sporn, J. R., B. B. Wolfe, T. K. Harden, and P. B. Molinoff (1977) Supersensitivity in rat cortex: Pre- and post-synaptic effects of 6-hydroxydopamine at noradrenergic synapses. Mol. Pharmacol. 13: 1170-1180.

Stricker, E. M., and M. J. Zigmond (1976) Recovery of function after damage to central catecholamine-containing neurons: $A$ neurochemical model for the lateral hypothalamic syndrome. In Progress in Psychobiology and Physiological Psychology, Vol. 6., pp. 121-188, Academic Press Inc., New York.

Thoenen, H., R. A. Mueller, and J. Axelrod (1969) Transsynaptic induction of adrenal tyrosine hydroxylase. J. Pharmacol. Exp. Ther. 169: 249-254.

Thoenen, H., R. A. Mueller, and J. Axelrod (1970) Phase differences in the induction of tyrosine hydroxylase in cell body and nerve terminals of sympathetic neurons. Proc. Natl. Acad. Sci. U. S. A. 65: 58-62.

Ungerstedt, U. (1971a) Adipsia and aphagia after 6-hydroxydopamine induced degeneration of the nigro-striatal dopamine system. Acta Physiol. Scand. Suppl. 367, 82: 95-122.

Ungerstedt, U. (1971b) Stereotaxic mapping of the monoamine pathways in the rat brain. Acta Physiol. Scand. Suppl. 367, 82: 1-29.

U'Pritchard, D. C., W. D. Bechtel, B. M. Roust, and S. H. Snyder (1979) Multiple apparent alpha-adrenergic receptor binding sites in rat brain: Effect of 6-hydroxydopamine. Mol. Pharmacol. 16: 47-60.

Uretsky, N. J., and L. L. Iversen (1970) Effects of 6-hydroxydopamine on catecholamine containing neurones in the rat brain. J. Neurochem. 17: 269-278.

Wilkinson, G. N. (1961) Statistical estimations in enzyme kinetics. Biochem. J. 80: 324-332.

Zigmond, M. J., and F. M. Stricker (1972) Deficits in feeding behavior after intraventricular injections of 6-hydroxydopamine in rats. Science 177: 1211-1214.

Zigmond, M. J., and E. M. Stricker (1974) Ingestive behavior following damage to central dopamine neurons: Implications for homeostasis and recovery of function. In Neurophysiology of Monoamines and Their Regulatory Enzymes, E. Usdin, ed., pp. 385-402, Raven Press, New York.

Zigmond, R. E. (1979) Tyrosine hydroxylase activity in noradrenergic neurons of the locus coeruleus after reserpine administration: Sequential increase in cell bodies and nerve terminals. J. Neurochem. 32: 23-29.

Zigmond, R. E., and A. Chalazonitis (1979) Long-term effects of preganglionic nerve stimulation on tyrosine hydroxylase activity in the rat superior cervical ganglion. Brain Res. 164: 137-152.

Zigmond, R. E., F. Schon, and L. L. Iversen (1974) Increased tyrosine hydroxylase activity in the locus coeruleus of rat brainstem after reserpine treatment and cold stress. Brain Res. 70: 547-552.

Zivkovic, B., A. Guidotti, and E. Costa (1974) Effects of neuroleptics on striatal tyrosine hydroxylase: Changes in affinity for the pteridine cofactor. Mol. Pharmacol. 10: 727-735. 